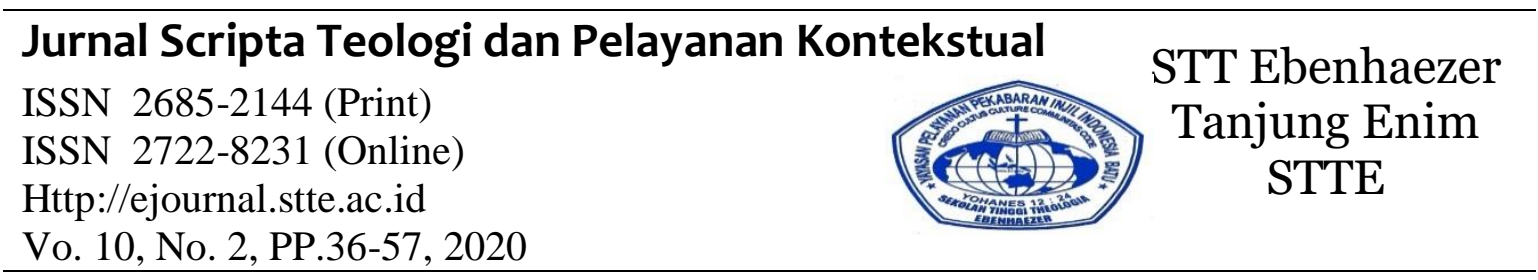

\title{
Pelayanan Tuhan Yesus Sebagai Pola Pelayanan Bagi Perempuan Kristen Dalam Konteks Adat Batak Toba Kurnia Sondang Lumban Gaol
}

Institut Injil Indonesia Batu, kurnialgaol@gmail.com

\begin{tabular}{l} 
INFO ARTIKEL \\
\hline Sejarah Artikel: \\
Diterima : 28-10-2020 \\
Direvisi : 17-11-2020 \\
Disetujui: 23-11-2020 \\
Dipublikasi: 28-11-2020
\end{tabular}

Kata Kunci:

Pelayanan, Yesus, Pola, Perempuan, Adat

Batak, Toba

Keywords:

Ministry, Jesus, Pola, woman, Customs

\begin{abstract}
Abstrak
Pemimpin dan kepemimpinan tidak dapat dipisahkan satu dengan yang lainnya. Apabila menyinggung tentang kepemimpinan, hal itu berkaitan dengan mendiskusikan suatu proses. Tetapi berbicara tentang pemimpin Kristen berarti berbicara tentang individu atau pribadi yang dipanggil oleh Tuhan untuk melaksanakan tugas kepemimpinan. Dewasa ini kepemimpinan dalam berbagai bidang telah diwarnai oleh terlibatnya wanita dalam memberikan peran sertanya dalam upaya meningkatkan pembangunan bangsa. Termasuk juga dalam kepemimpinan di gereja. Artikel ini akan memaparkan secara singkat tentang gambaran kepemimpinan wanita dalam gereja
\end{abstract}

\begin{abstract}
Leaders and leadership can not be separated from one another. If we mention the leadership, it relates to discuss the process. But talking about the Christian's leader is talking about private individuals or who are called by God to carry out the task of leadership. Today leadership in various fields has been characterized by the involvement of women in delivering participation in efforts to improve the development of the nation. Included the leadership in the church. This article will explain briefly about the image of women in church of leadership
\end{abstract}

\section{PENDAHULUAN}

Dalam pandangan Alkitab, laki-laki dan perempuan memiliki derajat yang sama di hadapan Allah. Tetapi dalam pandangan berbagai budaya, wanita sering dipandang lebih rendah dari laki-laki, termasuk dalam budaya Batak Toba. Di budaya Batak Toba laki-laki mempunyai peran penting dalam mengatur keluarganya dan meneruskan garis keturunan dari generasi ke generasi. Dalam kondisi ini, wanita dipandang sebagai pelengkap. Karena itu wanita Batak Toba begitu inferior dalam budayanya. Pelayanan kepada mereka menjadi penting untuk memberdayakannya demi peningkatan peran mereka dalam keluarga dan gereja Tuhan. Karena itu penting sekali melihat tentang bagaimanakah penilaian Alkitab terhadap perempuan dan bagaimana konsep Alkitab ini diterapkan dalam pelayanan kepada wanita Batak Toba? 


\section{PENGERTIAN KONTEKSTUALISASI}

Kata “kontekstualisasi” pertama kali muncul dalam terbitan TEF, yakni Theological Education Fund (Dana Pendidikan Teologi). Tujuan utama pekerjaan TEF ialah agar Injil diungkapkan dan pelayanan dilakukan sebagai tanggapan kepada: 1) krisis iman yang meluas; 2) masalah-masalah keadilan sosial serta pembangunan manusia; dan 3) ketegangan antara situasi-situasi budaya dan agama setempat dan peradaban teknologis yang universal. ${ }^{1}$ Konteks pembicaraan tentang kontekstualisasi dalam diskusi TEF adalah pendidikan teologi di negara-negara dunia ketiga.

Dalam perkembangannya, TEF memperlihatkan pemahaman sebagai berikut: 1) tekanan kuat pada pembaharuan di bidang teologi dengan dipusatkan pada konsep sentral, yaitu kontekstualitas, kemampuan untuk menanggapi Injil di dalam kerangka situasi perorangan dan komunitas; 2) kontekstulisasi tidak sekedar mode atau semboyan, tetapi suatu kebutuhan mendesak (imperatif kategoris) - yang dituntut Allah untuk menginkarnasikan Firman Allah; 3) kontekstualisasi otentik ialah bersifat profetis (kenabian) - yang selalu muncul dari pergumulan rangkap orang percaya, yaitu bergumul dengan kebenaran yang ia terima dari Allah dalam Yesus Kristus, atau menghayati kebenaran atau anugerah Allah dalam Yesus Krsitus, di pihak satu, dan sekaligus merupakan pergumulan dan pengharapan di tengah-tengah kebudayaan dan sejarah di mana seseorang itu hidup, di pihak lain. ${ }^{2}$

Namun, para misiolog menyadari bahwa ide dari kontekstualisasi itu sendiri sebenarnya sudah ada jauh sebelum TEF bersidang, yaitu terdapat di Kitab Suci. Contohnya adalah inkarnasi Yesus Kristus dan pendekatan Paulus pada waktu ia mengkomunikasikan Injil kepada orang bukan Yahudi (Kis. 17:16-34; 1 Kor. 9:19-23). Kebanyakan ahli evangelical menerima kata kontekstualisasi, tetapi memberikan definisi baru harus meng-ungkapkan kepekaan terhadap konteks dan kesetiaan kepada Alkitab. ${ }^{3}$

Secara sederhana istilah ini berarti upaya memberitakan Injil sesuai dengan konteks (kultur) pendengar. Dari istilah yang dipakai terlihat adanya kesadaran terhadap perbedaan kultur antara pemberita dan pendengar. Jika tidak dijembatani, perbedaan ini berpotensi untuk

menghalangi efektivitas pekabaran Injil, karena keberhasilan komunikasi terkait dengan pemahaman masing-masing pihak yang terlibat.

Kontekstualisasi mencakup dua aspek penting: kontekstualisasi teologi dan kontekstualisasi Injil. Aspek pertama berhubungan dengan usaha untuk membangun kerangka teologi yang Alkitabiah dan benar-benar bebas dari pengaruh pola pikir Barat. Aspek kedua lebih menyoroti tentang sikap dalam memberitakan Injil yang peka dan hormat terhadap perbedaan kultur yang ada antara pemberita dan pendengar. Jadi, kontekstualisasi teologi lebih ke arah isi, sedangkan kontekstualisasi Injil lebih bersentuhan dengan cara praktis yang dipakai.

Dengan demikian, dapat disimpulkan bahwa kontekstualisasi Injil sangat erat hubungannya dengan pengetahuan budaya dan worldview. Para misiolog dan teolog harus mengetahui tiga hal ini untuk dapat mempraktikkan kontekstualisasi dengan

\footnotetext{
${ }^{1}$ David J \& Rommen Edward Hesselgrave, Kontekstualisasi, Makna, Metode, Dan Model (Jakarta: BPK Gunung Mulia, 1996).48-49

2 Dkk Yewangoe, A.A, Kontekstualisai Pemikiran Dogmatika Di Indonesia (Jakarta: BPK Gunung Mulia, 1996).34-35

${ }^{3}$ David J, Kontekstualisasi, Makna, Metode, Dan Model.54
} 
sukses: pertama, konteks budaya dari Alkitab; kedua, konteks budaya mereka sendiri; dan ketiga, konteks budaya di sekeliling mereka di mana mereka melayani. ${ }^{4}$

Tentang hal tersebut, Peter Wongso menuliskan, bahwa obyek penginjilan adalah manusia, setiap manusia merupakan unsur pokok dalam masyarakat. Maka menginjili orang-orang dalam masyarakat harus memahami situasi masyarakat, dengan demikian baru dapat berhasil baik. ${ }^{5}$

Dalam pelayanannya di bumi, Yesus menghadapi banyak halangan budaya, antara lain adanya diskriminasi gender. Namun Yesus berhasil melakukan pelayanan dalam kondisi masyarakat dan budaya di mana IA berada.

Sebagai masyarakat yang paternalistik, bangsa Yahudi sangat menghargai laki-laki dan memandang rendah wanita. Pada zaman Yesus perempuan dianggap sebagai sumber semua kejahatan sebab mereka dianggap memiliki tempat di ladang, di sumur, atau di dapur. Mereka tidak diperkenankan berbicara dengan laki-laki di tempat umum (kecuali suami mereka sendiri), dan mereka tidak diperbolehkan menjadi saksi di pengadilan (sebab kesaksian perempuan dianggap tidak dapat dipercaya). ${ }^{6}$

Setiap laki-laki Yahudi bahkan diharuskan mengucap syukur dalam doa-doa mereka bahwa Allah telah menjadikan mereka sebagai laki-laki, bukan perempuan. Doa pagi yang dipanjatkan laki-laki Yahudi adalah, "Bersyukur kepada Allah, saya dilahirkan bukan sebagai orang kafir, atau seorang budak, atau seorang perempuan”. ${ }^{7}$ Perempuan hanya dianggap sebagai properti belaka, walaupun dalam Perjanjian Lama terdapat figur perempuan yang cukup terkenal, misalnya Miriam, Debora, Ruth, Hana. Konsep tersebut jelas sangat mempengaruhi sikap laki-laki Yahudi terhadap wanita. Sebuah tradisi bahkan menjelaskan bahwa seorang rabi Yahudi tidak boleh melihat maupun berbicara dengan wanita di jalan.

Yesus menyadari situasi ini dan Dia tidak mau terikat oleh hal-hal yang bersifat temporal dan kultural seperti ini. Dia memberikan penghargaan yang lebih tinggi kepada perempuan. Pelayanan-Nya didukung secara finansial oleh para perempuan kaya (Luk. 8:1-3). Dia memperhatikan janda (Luk. 7:12-13), perempuan yang najis oleh pendarahan (Mat. 9:20-22) maupun perempuan berdosa (Luk. 7:37-48).

Sikap yang kurang menghargai ini juga terjadi juga dalam masyarakat Batak. Sistem kekerabatan orang Batak Toba yang dikenal dengan istilah Dalihan $\mathrm{Na}$ Tolu bersifat patrilineal, mewakili tiga kelompok fungsional. Pertama, dongan sabutuha, yaitu kelompok kekerabatan yang terdiri dari para lelaki seketurunan atau semarga. Kedua, hula-hula, yaitu pihak mertua dan saudara-saudara laki-laki semarga. Ketiga, Boru, yaitu pihak menantu. Dengan demikian, laki-laki menjadi pemeran utama dalam kehidupan masyarakat Batak. Sifat patrilineal terwujud dalam berbagai bidang kehidupan (perkawinan, hukum, warisan, pemilikan tanah, dan pola tempat tinggal). ${ }^{8}$ Dengan sistem yang demikian, maka posisi perempuan dalam hukum adat Batak Toba tergolong lemah, baik dalam lembaga perkawinan maupun institusi adat. Perempuan bukan sebagai subyek, melainkan sebagai obyek untuk mendukung status dan dan martabat kaum laki-laki sebagai pembawa marga. Perempuan yang sudah menikah pun tidak akan pernah mendapatkan status yang sama dengan laki-laki dalam hukum adat kendati ia

\footnotetext{
${ }^{4}$ Rahmiati, "Veritas" 1, no. April (2000).

${ }^{5}$ Wongso Peter, Tugas Gereja Dan Misi Masa Kini (Surabaya: Yakin, 1981).104

${ }^{6}$ J. Lee Grady, 10 Kebohongan Yang Diberitahukan Gereja Kepada Wanita (Batam: Gospel Press, 2004).27

${ }^{7}$ Jhon Stott, Isu-Isu Global (Yayasan Bina Kasih/OMF, 1994).335

${ }^{8}$ Rainy Hutabarat, "Perempuan Dalam Budaya Batak: Boru Ni Raja, Inang Soripada Dan Pembuka

Hubungan Baru, ” 55th ed. (Gema Duta Wacana, 1999).81-82
} 
juga bekerja mencari nafkah bagi keluarga. Dalam masalah hutang piutang, pihak ketiga sebagai saksi tidak boleh seorang perempuan. ${ }^{9}$

Dengan menempatkan posisi perempuan hanya sebagai obyek, maka peran perempuan Batak Toba menjadi sangat terbatas. Sebagai pribadi, perempuan Batak tidak dapat mengaktualisasikan dirinya dengan segala potensi yang ada.

Penilaian yang demikian terhadap kaum perempuan dalam masyarakat Batak Toba tentu menyimpang dari hakikat penciptaan, bahwa perempuan diciptakan Allah sederajat dengan laki-laki. Perempuan dan laki-laki mempunyai tugas dan tanggung jawab yang sama untuk menaklukan dan memenuhi bumi. Dengan demikian seluruh potensi yang ada dalam diri perempuan seharusnya dapat diberdayakan untuk memenuhi tugas dan tanggung jawab tersebut. Sekalipun konsep berpikir masyarakat Batak Toba sudah sedemikian melekat dari generasi ke generasi, tetapi bukan berarti bahwa konsep tersebut tidak dapat diperbaiki. Yesus datang menyelamatkan manusia, bukan hanya laki-laki tetapi juga perempuan. Kehadiran Yesus dalam lingkungan masyarakat Yahudi mengangkat martabat perempuan dalam konteks budaya yang merendahkan mereka.

\section{BENTUK PELAYANAN TUHAN YESUS PADA PEREMPUAN}

\section{Dalam Keluarga}

\section{Perempuan Sebagai Ibu Yang Dipilih Allah}

Di kalangan Yahudi, dianggap bahwa tempat perempuan adalah di rumah. ${ }^{10}$ la menjadi penolong yang harus tunduk pada suami dan melahirkan anak-anak bagi suaminya (band. Amsal 31:10-31). Menjadi seorang ibu, adalah sebuah kewajiban semata. Namun, fakta bahwa inkarnasi Yesus Kristus terjadi dan mengekspresikan diri dalam dan melalui kebudayaan. ${ }^{11}$ Di dalam karya Keselamatan Allah bagi manusia, Tuhan Yesus lahir dari rahim seorang perempuan.

Dengan demikian, perempuan adalah pribadi yang istimewa dalam pandangan Allah, berbeda dengan budaya yang ada pada masa itu. Menjadi seorang ibu bukanlah sekedar kewajiban perempuan semata, dalam pandangan Allah itu adalah status yang penting. Karena Allah berkenan memakai seorang ibu untuk melahirkan Juruselamat (Lukas 1:26-28). Tentang hal ini Donald Guthrie menuliskan, "ia menjadi alat yang dipakai Allah untuk menjelmakan diri-Nya dalam diri manusia. Tentu saja Allah dapat memilih cara lain, tetapi Yesus masuk ke dalam dunia sebagai manusia, sama seperti semua manusia yang lain, melalui rahim seorang perempuan." 12

\section{Dalam Masyarakat}

\section{Sebagai Pribadi yang Mendapat Perhatian dan Pemulihan}

Dalam kehidupan orang Yahudi yang tidak terlalu mengindahkan perempuan, Tuhan Yesus memberikan perhatian, kasih dan pemulihan sesuai dengan apa yang mereka perlukan. Yesus menyembuhkan ibu mertua Simon yang sakit demam, sehingga ia dapat bangun dan melayani Yesus dan rombongannya. (Lukas 4:38-39).

Yesus melakukan mujizat karena belas kasihan-Nya kepada janda Nain (Lukas 7:1117). Pada masa itu, nasib seorang janda biasanya sangat menyedihkan, apalagi jika anak

\footnotetext{
9 J.C. Vergouwen, Masyarakat Dan Hukum Adat Batak Toba (Jakarta: Pustaka Azet, 1986).337

${ }^{10}$ Grady, 10 Kebohongan Yang Diberitahukan Gereja Kepada Wanita.872

${ }^{11}$ Y. Tomatala, Teologi Kontekstualisasi: Suatu Pengantar (Malang: Gandum Mas, 2007).74

${ }^{12}$ Donald Guthrie, Teologi Perjanjian Baru I (Jakarta: BPK Gunung Mulia, 1991). 156
} 
laki-laki satu-satunya meninggal dunia. Ketka Yesus melihat janda itu, tergeraklah hatiNya oleh belas kasihan. Sekalipun menurut Taurat bahwa Yesus akan menjadi najis karena menyentuh usungan mayat (band. Bilangan 19:11, 16), Yesus mengabaikan hal itu. Dengan perkataan-Nya, anak muda itu hidup kembali.

Hukum Israel menetapkan, bahwa seorang perempuan yang mengalami pendarahan adalah najis (band. Imamat 15:25). Kemungkinan hal itulah yang membuat perempuan sakit pendarahan tidak berani menghadap Yesus di depan umum. ${ }^{13}$ la menjamah jumbai jubah Tuhan Yesus dengan sembunyi-sembunyi. Ketika perbuatannya diketahui Yesus, perempuan itu gemetar dan tersungkur. Namun Yesus melihat imannya, dan perempuan itu sembuh (Lukas 8:40-56).

Di dalam kisah perempuan bungkuk, tampak sikap yang berbeda antara TuhanYesus dengan kepala rumah ibadat (Lukas 13:10-17). Kepala rumah ibadat mengutamakan hukum akan hari Sabat dan mengabaikan penderitaan perempuan itu, sebagaimana yang dituliskan oleh Leon Moris, pemimpin sinagoge tidak senang karena penyembuhan itu terjadi pada hari Sabat; bagi dia Sabat lebih penting daripada pelepasan derita wanita itu. Namun sikap Yesus sangat berbeda dengan sikap orang itu dan sikap orang-orang Farisi lainnya. ${ }^{14}$ Yesus penuh kasih lebih mengutamakan penyembuhan,

\section{Sebagai Janda}

Sekalipun cerita dalam Lukas 18:1-8 adalah sebuah perumpamaan yang dipergunakan Yesus untuk menunjukkan bahwa Allah akan membenarkan dan menolong orang yang percaya, kemungkinan Yesus telah mengangkat realita. Dalam masyarakat pada masa itu, janda adalah kelompok masyarakat yang seringkali harus menderita karena ketidakadilan akau kesewenangan. Namun, bagi seorang janda yang gigih dan terus-menerus meminta keadilan, maka akhirnya akan memperolehnya. Tentang hal ini Witherington (dalam Cindy Jacobs) menuliskan,

Pilihan Yesus pada seorang wanita yang membutuhkan pertolongan sebagai contoh bagi murid-murid-Nya mungkin menandakan simpati Yesus dan kepedulian-Nya terhadap orang-orang dalam kelompok masyarakat berorientasi pria ini, dan juga karena unsur dari tingkah laku wanita ini yang dipusatkan oleh Yesus (kekerasan hati dan ketekunannya) dalah karakter masyarakat patriatkhal yang sering dipandang sebagai akibat negatif oleh seorang wanita (Amsal 19:13). ${ }^{15}$

Di dalam Lukas 21:1-4, disampaikan tentang seorang janda lain yang rela memberikan semua apa yang ada padanya bagi Tuhan. Tentang kisah tersebut, Lukas mencatat, bahwa Yesus mempunyai waktu untuk memperhatikan seorang janda miskin yang memberi dua keping uangnya sebagai persembahan. Yesus memandang bahwa pemberian janda itu penting, sehingga ia menunjukkan hal itu kepada murid-murid-Nya. Yesus melihat pemberian orang-orang kaya, tetapi IA tidak memuji mereka. Namun Yesus memuji dan menghargai perbuatan janda tersebut. Mungkin masyarakat lebih menghargai orang-orang kaya itu, tetapi bagi Yesus, janda tersebut adalah contoh pribadi yang saleh dan tidak kuatir akan dirinya.

\footnotetext{
${ }^{13}$ Lembaga Biblika Indonesia, Injil Lukas (Yogyakarta: Kanisius, 1981).107

${ }^{14}$ Leon Morris, Teologia Perjanjian Baru (Malang: Gandum Mas, 1996).285

${ }^{15}$ Cindy Jacobs, Wanita Pilihan Allah (Yogyakarta: Yayasan Andi, 1999).41
} 


\section{Perempuan Sebagai Saksi}

Pada masa itu, secara hukum, bagi orang Romawi perempuan tidak dianggap sebagai saksi-saksi yang dapat dipercaya. Laki-laki diajar bahwa kesaksian seorang perempuan tidak boleh dipercaya, sebab perempuan dipandang bodoh dan mudah tertipu. ${ }^{16}$ Leon Morris juga mencatat bahwa perempuan Yahudi juga tidak boleh menjadi saksi di pengadilan. ${ }^{17}$ Namun Yesus justru menyatakan kebangkitan-Nya kepada kaum perempuan, dan member perintah kepada mereka untuk menyaksikan peristiwa tersebut kepada murid-murid-Nya. Untuk membenarkan kesaksian kaum perempuan yang kurang dipercaya para murid, Yesus kemudian menampakkan diri kepada mereka sebagai bukti kebangkitan-Nya.

Dengan memberikan tanggung jawab kepada kaum perempuan menjadi saksiNya, Yesus menyatakan bahwa la tidak menilai rendah perempuan sebagaimana budaya menilai mereka. Bagi Yesus baik perempuan maupun laki-laki, semua sama-sama dapat menjadi saksi yang dapat dipercaya.

\section{Dalam Religi}

\section{Perempuan sebagai Nabiah dan Janda yang Saleh}

Hana adalah seorang nabi perempuan yang menantikan Juru Selamat (Lukas 2:3638). Hana adalah saksi mula-mula yang memberitahukan tentang Yesus yang adalah Juru Selamat kepada semua orang yang menantikan kelepasan. la tahu bahwa semua orang di Yerusalem telah menanti-nantikan kedatangan Juru Selamat. la pergi memberitahukan kepada mereka tentang apa yang dilihatnya. ${ }^{18}$

\section{Perempuan Menjadi Pelayan Yesus}

Pada masa itu, budaya menanggap bahwa perempuan hanyalah sebagai milik lakilaki. Tanggung jawab mereka hanya bersifat domestik, yaitu mengurus rumah dan keluarga. Mereka kurang berperan dalam kegiatan ibadah. Namun Yesus mengijinkan para perempuan dalam perjalanan pelayanan-Nya (Lukas 8:1-3). Mereka tidak hanya ikut dalam perjalanan tetapi juga melayani rombongan yang ada dengan kekayaannya. Bagi Yesus, baik laki-laki maupun perempuan memiliki kesempatan yang sama untuk melayani. Kaum perempuan dapat melayani dengan apa yang mereka miliki. Yesus menentang prasangka gender dari budaya masa itu dengan memperbolehkan perempuan mengikuti-Nya. ${ }^{19}$

Bahkan Injil Lukas mencatat tentang kesetiaan mereka dalam mengikuti Yesus. Di kemudian hari beberapa perempuan itu menjadi saksi kematian Yesus di kayu salib (Lukas 23:49), dan saksi kebangkitan-Nya (Lukas 24:10). Tentang hal ini Norval Geldenhuys menuliskan demikian,

These women, or several of them at least, continued throughout the rest of Jesus public ministration, until His crucifixion, to follow and serve Him. And when all His disciples (except the beloved disciple) had fled, some of the woman attended Him as far as Golgotha (Jhon xix.25) and even as far as the grave, where they were also the first witnesses of His resurrection (cf.xxiii. 49,55,xxiv,1-10). ${ }^{20}$

\footnotetext{
${ }^{16}$ Grady, 10 Kebohongan Yang Diberitahukan Gereja Kepada Wanita.108

${ }^{17}$ Morris, Teologia Perjanjian Baru.282

${ }^{18}$ Pr. St Darmawijaya, Perempuan Dalam Perjanjian Baru (Yogyakarta: Kanisius, 1991).35

${ }^{19}$ Grady, 10 Kebohongan Yang Diberitahukan Gereja Kepada Wanita.69

${ }^{20}$ Norval Geldenhuys, The Gospel Of Luke (Grand Rapids, Michigan: W.M.B Eerdmans Publising Company, 1979).239
} 


\section{Perempuan sebagai Murid}

Salah satu peran penting kaum perempuan adalah melakukan pekerjaan rumah, menyediakan makan dan minuman, atau mengerjakan hal-hal yang bersifat praktis. Kisah tentang Maria dan Marta (Lukas 10:38-42) memaparkan bahwa kaum perempuan bukan hanya melakukan hal-hal praktis semata, tetapi juga perlu memberikan perhatian pada perkara rohani di dalam hidupnya. Marta telah melakukan perannya dengan baik sebagai perempuan, tetapi Maria telah melakukan yang lebih baik, yaitu memberikan waktu untuk mendengarkan pengajaran Yesus. Yesus dengan tegas mengatakan bahwa kaum perempuan pun harus seperti Maria, menjadi murid, belajar tentang perkaraperkara rohani.

Bagi Yesus, baik laki-laki maupun perempuan, semua harus menjadi murid Tuhan Pernyataan Yesus tentang Maria, bertentang dengan budaya pada masa itu, yang tidak memberikan kesempatan kepada perempuan untuk belajar, sebagaimana Leon Morris menuliskan, "jika Yesus menganggap normal bahwa kaum wanita menerima pengajaran-Nya, suatu hal yang sangat berbeda dengan sikap para rabi". ${ }^{21}$

\section{Simpulan}

Berdasarkan uraian di atas, dapat dismpulkan bahwa ada beragam latar belakang perempuan dalam kehidupan pelayanan Yesus. Sikap Yesus terhadap mereka berbeda dengan sikap masyarakat dan budaya yang ada. Yesus menyadari situasi ini dan Dia tidak mau terikat oleh hal-hal yang bersifat temporal dan kultural. Jika budaya memandang perempuan dengan rendah, tetapi Yesus justru menghargai mereka. Yesus menyatakan bahwa kedatangan-Nya ke dunia tidak hanya mengasihi kaum laki-laki, tetapi IA datang untuk semua orang.

Pada dasarnya perempuan diciptakan Allah sederajat dengan laki-laki. Keduanya diciptakan menurut gambar dan rupa Allah, sama-sama memiliki kemuliaan dan sifatsifat Allah. Dengan demikian, perempuan bukanlah ciptaan yang memiliki status yang lebih rendah dan bukan bawahan dari laki-laki. Keduanya memiliki kedudukan dan mandat yang sama (Kej. 1:27-28). Proses penciptaan yang dipaparkan dalam Kejadian 2 juga menggambarkan kesetaraan antara laki-laki dan perempuan, Allah mengambil salah satu tulang rusuk Adam untuk menciptakan Hawa. "Kisah ini menunjukan betapa pentingnya wanita itu bagi pria; dia merupakan bagian wujud pria, dan tanpa dia pria tidaklah lengkap". ${ }^{22}$

Perbedaan antara laki-laki dan perempuan bukan merupakan perbedaan yang bersifat kualitatif. Kualitas perempuan tidaklah lebih rendah dari laki-laki, sehingga lakilaki bukanlah ciptaan yang lebih mulia. Sebab itu, perempuan bukanlah ciptaan yang lebih hina dari laki-laki. Laki-laki dan perempuan sama-sama diberkati dan sama-sama mendapatkan tugas untuk menaklukan dan memenuhi bumi (Kej. 1:28). Tentang hal ini Stott menyatakan, "tidak terdapat suatu hunjukan dalam natsnya bahwa salah satu dari kedua seks itu lebih besar keserupaannya dengan Allah dari pada yang lain, atau bahwa dari salah satu dari kedua seks itu lebih besar tanggung jawabnya atas bumi dari pada yang lain. ${ }^{23}$ Demikian juga Evans menyatakan, “... man \& woman as different but united,

\footnotetext{
${ }^{21}$ Morris, Teologia Perjanjian Baru.284

22 Jr Packer, J.L., Meril C.Tenney, William White., Ensiklopedi Fakta Alkitab 2 (Malang: Gandum Mas, 2001).867

${ }^{23}$ Stott, Isu-Isu Global.335
} 
eachthe perfeck complement of the other, each playing his or her part in the God-given tasks of filling and governing the earth.... ${ }^{24}$ Perintah untuk berkuasa tidak ditunjukan hanya kepada Adam, tetapi juga kepada Hawa. Dengan demikian Allah memberikan potensi dan kemampuan yang sama dalam mengerjakan tanggung jawab yang Allah berikan.

Kenyataan bahwa Hawa diciptakan sebagai penolong bagi laki-laki, sebenarnya tidak boleh ditafsirkan bahwa laki-laki memiliki kekuasaan atas perempuan, sebagaimana yang ditentukan oleh Griffiths (dalam Lees) berikut ini

The Hebrew word "helper" occurs twenty one times in the Old Testament. Apart from its use twice here of the women, four of these occurrences are general usages and the other fifteen are references to God as the "helper" of His people; so it cannot in itself mean that the "helper" is secondary and subordinate to the helper. ${ }^{25}$

Kata ezer (bahasa Ibrani) dalam Kejadian 2:18 yang berarti helper (penolong), ${ }^{26}$ tidak dapat diartikan budak atau pelayan. Sebagaiman yang dipakai dalam istilah "Ebenhaezer" yang berarti 'sampai di sini Tuhan menolong', maka jika perempuan dikatakan sebgai penolong, itu berarti bahwa perempuan memiliki "sifat Allah" sebagai penolong. Pada saat Allah digambarkan sebagai penolong, maka bukan berarti bahwa la memiliki kedudukan yang lebih rendah dari manusia yang ditolong-Nya. Tentang hal ini Mary Evans juga menyatakan pendapat yang sama,

It can be said, however, that the use of the word "helper" of it self cannot be seen as implying inferiority or subordination in any sense. The helper fit for men is his counterpart, his complement, his partner, his companion and his associate, bone of his bone, and flesh of his flesh. ${ }^{27}$

Terhadap "penolongnya" seharusnya laki-laki menempatkan diri sebagai seseorang yang membutuhkan pertolongan agar ia dapat melaksanakan tugas dan panggilan Allah untuk beranak cucu dan menaklukan bumi (Kej. 1:28). Seorang laki-laki tidak akan dapat mengerjakan tugas itu seorang diri, oleh sebab itu ia membutuhkan perempuan sebagai penolong baginya. Laki-laki dan perempuan sama-sama diberkati dan sama-sama mendapatkan tugas untuk menaklukkan dan memenuhi bumi.

\section{STATUS DAN PERAN PEREMPUAN DALAM ADAT BATAK TOBA}

Mengenai status dan peran perempuan dalam adat Batak Toba akan dipaparkan dalam beberapa aspek, yaitu dalam keluarga (kekerabatan dan perkawinan), dalam kehidupan masyarakat, dan dalam religi.

\section{Dalam Keluarga \\ Dalam Kekerabatan}

Di dalam keluarga, hanya anak laki-laki yang diharapkan dapat memelihara kelangsungan keturunan dan menjadi ahli waris yang sah. Anak laki-laki yang memiliki hak penuh atas semua peninggalan keluarga. Anak laki-laki sulung merupakan pemimpin bagi saudara-saudaranya, baik dalam urusan adat ataupun dalam mewakili orang tua. Adalah kewajiban bagi saudara laki-laki utnuk membela, melindungi, dan menolong saudara perempuan. Mereka juga tidak boleh berlaku kasar. Perlindungan dan bantuan itu mencakup masalah kehidupan adat, keluarga, rumah tangga, dan sebagainya.

\footnotetext{
${ }^{24}$ Mary Evans, Women in the Bible (England: Itervarsity Press, 1984).21

${ }^{25}$ Shirley Lees, The Role Of Women (England: Intervarsity Press, 1984).75

${ }^{26}$ John Joseph Owens, Analytical Key to the Old Testament Vol I (Grand Rapids, Michigan: Beker Book House, 1994). 9

${ }^{27}$ Evans, Women in the Bible.16-17
} 
Apabila ada acara atau kegiatan di dalam keluarga anak laki-laki, maka saudaranya yang perempuan dan para suami (bagi yang sudah menikah) sebagai pihak boru harus berada di belakang, berperan sebagai parhobas (pekerja), atau penyedia dalam kegiatan tersebut. Sedangkan saudara laki-lakinya berada di depan.

Sebagai boru, seorang perempuan dan suaminya harus menghormati saudara lakilaki mereka (hula-hula). J.C. Vergouwen menuliskan bahwa hula-hula adalah sumber kekuatan adikodrati dan daya hidup bagi masing-masing borunya. Ini berarti boru harus menghindari perbuatan yang dapat merugikan atau menyakiti hula-hula, dan boru tidak boleh lupa menunjukkan rasa syukurnya terhadap kebajikan yang diperoleh dari hulahulanya. Jika seorang boru mempunyai alasan untuk mengeluh terhadap hula-hulanya, dia tidak boleh terlalu bersikeras memegang haknya. Jika terlanjur terjadi pertengkaran, maka boru harus mengaku bersalah, dan berusaha untuk memulihkan kerukunan dengan mempersembahkan makanan. Jika boru mengalami kesusahan atau ketidakberuntungan dalam kehidupan pribadi atau rumah tangganya, maka ia harus memohon kepada hula-hula agar mereka dihindarkan dari hal-hal tersebut. ${ }^{28}$

\section{Dalam Perkawinan}

Hanya melalui perkawinan dan melahirkan anak laki-laki, seorang perempuan memiliki makna dan martabat kemanusiannya dalam masyarakat Batak. Dalam sistem kekerabatan, posisi perempuan adalah "penempa mata rantai baru". la membuka hubungan kekerabatan baru melalui perkawinan. Tanpa perkawinan ia tidak mempunyai status dan martabat apapun dalam masyarakat Batak. ${ }^{29}$ Pada hakikatnya, perkawinan tersebut sepenuhnya bersifat patrilineal. Tujuannya ialah melestarikan keturunan dalam garis marga laki-laki. Hak tanah, milik, nama, jabatan, hanya dapat diwarisi oleh keturunan laki-laki.

Perkawinan merupakan "harga mempelai" perempuan. Perempuan dilepaskan dari kelompoknya dengan pembayaran sejumlah uang yang telah disetujui bersama, atau dengan penyerahan benda berharga. Yang bertanggung jawab atas penyelenggaraan perkawinan, yaitu bapaknya. Jika sang bapak sudah meninggal, digantikan kakak laki-lakinya. Jika kakak laki-laki masih terlalu muda, atau tidak mempunyai saudara laki-laki, tanggung jawab itu bisa dipikul kakak laki-laki bapaknya. Dalam konteks ini, kerabat tersebut dinamai parboru (arinya: dia yang memiliki anak perempuan). ${ }^{30}$ Sebagai kepala keluarga, suami adalah yang memerintah dalam rumah. Suami adalah penguasa atas isteri, anak-anak, dan atas harta benda. Dia melayani dan dilayani menurut kemuannya. ${ }^{31}$

Oleh karena tujuan utama perkawinan adalah memperoleh keturunan laki-laki yang sah, maka menurut alam pikiran orang yang belum memeluk agama, tidak mempunyai keturunan laki-laki berarti hidup sengsara di alam baka. ${ }^{32}$ Oleh sebab itu, kemandulan bisa menjadi penyebab perceraian. Sering terjadi, pihak keluarga perempuan yang mandul, jika anak perempuannya dikembalikan kepada orang tuanya,

\footnotetext{
${ }^{28}$ J.C Vergouwen, Masyarakat Dan Hukum Adat Batak Toba (Jakarta: Pustaka Sinar Harapan, 1988).62-63

${ }^{29}$ Hutabarat, "Perempuan Dalam Budaya Batak: Boru Ni Raja, Inang Soripada Dan Pembuka Hubungan

Baru. "'86-87

${ }^{30}$ Vergouwen, Masyarakat Dan Hukum Adat Batak Toba, 1988.175

${ }^{31}$ Vergouwen. 242

${ }^{32}$ Vergouwen. 183
} 
maka keluarga akan segera me-nyediakan perempuan yang lain untuk menggantikannya. ${ }^{33}$

Kemandulan isteri dipandang sebagai sesuatu yang merendahkan martabat sang suami, dan bila di antara anak-anaknya tidak ada anak laki-laki, hal itu akan dipandang sebagai suatu penghinaan yang menodai martabat pihak suami dan keluarganya. Oleh sebab itu, pada upacara-upacara, perayaan, dan pesta-pesta adat, orang akan selalu memohon supaya keluarga yang mengadakan pesta itu mendapat kekayaan, banyak anak, sehat dan murah rezeki. Hal ini biasanya disampaikan dengan peribahasa "Bintang na rumiris, ombun na sumorp, Anak per iris, boru pe antong torop" (artinya: bintang bertaburan, embun bergumpal menutup padang, anak laki-laki berbaris-baris, anak perempuan tak kurang); "Lak-lak ni singkoru na gantung di ginjang pintu, Maranak sampolu tolu, marboru sampulu pitu" (artinya: kulit saga-saga digantung di atas pintu, mempunyai anak laki-laki tiga belas, anak perempuan tujuh belas). Hanya anak laki-laki yang diharapkan dapat memelihara kelangsungan keturunan (oleh sebab itu dianggap wajar kalau seorang suami yang tidak mempunyai anak laki-laki dari seorang isteri, mengambil isteri lain yang diharapkan dapat memberikan anak laki-laki padanya). ${ }^{34}$

Menurut S.H.W. Sianipar ada enam sebutan yang diberikan kepada perempuan yang menikah, yaitu ripe, tunggane boru, na nialap, paniaran, parsinonduk, dan pardibagas. Dari sebutan tersebut dapat diketahui bagaimana peran perempuan dalam perkawinan/ rumah tangga, juga kesalahan dan kebenaran perempuan sebagai isteri. Namun, dengan melihat keenam hal tersebut tidaklah mudah menceraikan seorang isteri di dalam hukum perkawinan Mulajadi Na Bolon.

Ripe, artinya kawan atau teman dalam kerjasama untuk membangun atau melaksanakan satu rencana yang baik, dalam susah atau senang. Seorang yang disebut ripe belum tentu ia adalah seorang isteri yang sah. Dengan sebutan ini, peran seorang isteri adalah menjadi rekan suaminya untuk melaksanakan rencana atau kegiatan dalam rumah tangga mereka. Seorang isteri dapat disalahkan jika dalam rumah tangga, ia tidak menunjukkan kerjasama yang baik dengan suaminya.

Tunggane boru atau tugani boru, artinya dapat diharapkan melakukan pekerjaan. Arti kata lain ialah tanggung jawab perempuan. Kata tugan atau tuga mengandung arti keyakinan dan percaya bahwa yang bersangkutan akan melaksanakan tugasnya, karena memang pengetahuan dan keahliannya khusus untuk itu (yaitu mengurus rumah tangga). Orang Batak dulu boleh memiliki banyak ripe, tetapi yang disebut tunggane boru hanya satu, sebab yang lain hanya sebagai pangurupi (pembantu) bagi tunggane boru yang sah menurut adat. Tunggane Boru adalah sebutan hanya bagi perempuan yang sudah sah menjadi isteri secara adat.

Na nialap artinya yang dijemput dengan adat dari rumah orang tuanya. Pengertian kata dialap ini menyatakan bahwa pihak laki-lakilah yang memerlukannya menjadi isteri. Apabila seorang perempuan menjadi isteri karena diantar oleh orang tuanya (seperti pada adat taruhon jual), maka isteri tersebut tidak boleh disebut na nialap, karena ia adalah pemberian orang tuanya kepada pihak laki-laki. Dalam kondisi demikian, maka isteri tersebut menjadi penolong (pangurupi) isteri pertama/ isteri yang sah (tunggane boru). Seorang isteri yang disebut na nialap tidaklah mudah untuk diceraikan, karena ada ketentuan adat yang harus dipenuhi untuk melakukan hal tersebut, kecuali jika ia

\footnotetext{
${ }^{33}$ Vergouwen. 274

${ }^{34}$ A.M Lumban Tobing, Makna Wibawa Jabatan Dalam Gereja Batak (Jakarta: BPK Gunung Mulia, 1996).24-25
} 
berselingkuh. Sedangkan ripe yang ditaruhon jual, dapat diceraikan setiap saat apabila ia dianggap tidak diperlukan lagi. Sebab ia hanya dianggap sebagai pembantu isteri yang sah.

Paniaran artinya penjemuran. Pada masa lalu, apabila seorang laki-laki sudah menentukan pilihannya, agar pilihan itu tidak diganggu oleh pemuda lain, maka di samping pintu rumahnya digantungkan hohos atau tali. Pemakaian kata paniaran terhadap isteri yang sah adalah salah, karena setelah menikah ia disebut na nialap. Kata paniaran juga berkaitan dengan kata siar, yang berarti pemberitahuan kepada khalayak ramai bahwa seorang gadis telah dipersiapkan menjadi isteri seorang laki-laki.

Parsinonduk artinya yang memasak dan menghidangkan makanan untuk suaminya, dan siapa saja yang datang ke rumahnya (tamu). Dengan sebutan ini, seorang suami tidak boleh mencampuri atau mencurigai isterinya berkaitan dengan perannya ini, karena masalah makanan di dalam rumah adalah hak mutlak isteri untuk mengaturnya. Seorang isteri yang tidak menyadari atau tidak peduli dengan perannya sebagai parsinonduk (sehingga ia tidak menyediakan makanan bagi suaminya), berarti ia telah melakukan kesalahan besar.

Pardibagas atau pardijabu, artinya yang berkuasa di dalam rumah, mengatur, menjaga, membersihkan, dan selalu harus berada di dalam rumah jika suaminya kembali atau pulang dari pekerjaannya. Karena itu, seorang suami yang tidak mempercayai isteri dalam mengelola rumah tangganya bertentangan dengan adat pardibagas/ pardijabu. ${ }^{35}$

Selain sebutan di atas, menurut J.C. Vergouwen, seorang isteri disebut juga inanta soripada (raja rumah yang dimuliakan), apalagi jika ia mempunyai anak. Isterilah yang menjadi pusat rumah dan "roh pembawa keselamatan". Dialah yang memberi anak lakilaki dan perempuan bagi suaminya, mengelola rumah tangga, berusaha menambah penghasilan keluarga, menyediakan makanan dan minuman bagi tamu agar suaminya disegani, dan rumah tangganya dihormati dan dipuji orang. ${ }^{36}$

Jika seorang perempuan menjadi janda karena kematian suaminya, maka kuasa atas isteri berpindah ke keluarga terdekat suami, jika tidak ada keturunan laki-laki. Namun, jika seorang isteri memiliki anak laki-laki tertua, tetapi belum dewasa, maka keluarga dapat bertindak atas nama anak-laki-laki tersebut. Seorang janda (na mabalu), bisa tetap tinggal di bawah kuasa dan di dalam lingkungan kerabat suaminya, atau ia dapat kembali pada keluarga sendiri. Seorang janda dapat menikah lagi dengan seorang dari kelompok keluarga suaminya atas dasar adat "ganti tikar". Keluarga juga dapat menikahkannya dengan anggota keluarga jauh, anggotadari marga yang sama dengan suaminya terdahulu, ataupun dengan laki-laki dari marga lain. Semua kemungkinan tersebut mempunyai konsekuensi yang berbeda. ${ }^{37}$ Janda yang sudah menikah lagi adatnya ditentukan oleh suaminya yang baru.

Apabila seorang janda tidak menikah lagi tetapi memiliki anak laki-laki yang belum dewasa, maka ia dapat menangani harta peninggalan suamninya, dan mengelolanya sampai anak laki-lakinya yang tertua dewasa. Namun, penguasaan tersebut hanya sebatas pada pengeluaran belanja sehari-hari, pemeliharaan dan penggunaan hak milik. Jika hanya memiliki anak-anak perempuan, maka ia akan bergantung pada kebaikan ahli waris suaminya. Kebergantungan juga terjadi pada janda yang tidak menikah dan tidak

\footnotetext{
${ }^{35}$ S.H.W Sianipar, Tuho Parngoluan, Ruhut Ni Adat, Poda Ni Uhum, Pangalaho Ni Padan (Medan: Pustaka Gama, 2001).28-35

${ }^{36}$ Vergouwen, Masyarakat Dan Hukum Adat Batak Toba, 1988.242

${ }^{37}$ Vergouwen.262
} 
mempunyai anak. la bukan bergantung pada kebaikan ahli waris suaminya (karena memang tidak memiliki hak untuk itu), tetapi bergantung pada keluarga atau kerabatnya sendiri (hula-hula). Namun, seringkali terjadi, bahwa kerabatnya sendiri bersikap sewenang-wenang, dan tidak memberikan bantuan kepadanya. ${ }^{38}$

\section{Dalam Masyarakat}

Dalam masyarakat Batak Toba, seseorang disebut dewasa tidak ditentukan oleh umurnya, tetapi oleh status pernikahan. Jika seseorang sudah menikah, barulah ia dinyatakan dewasa dan dapat menjadi anggota penuh dari masyarakat. Sebagai orang dewasa, ia dapat terlibat dalam perundingan dan bertanggung jawab dalam perkembangan di desanya. ${ }^{39}$

Seorang perempuan (boru) yang belum menikah ikut dalam marga ayahnya, tetapi ketika menikah maka ia akan menjadi bagian marga suaminya. Di hadapan marga ayahnya, ia dan suaminya disebut sebagai pihak boru. Dengan demikian di dalam hidup bermasyarakat, eksistensi perempuan Batak Toba tergantung pada ayah atau suaminya.

Namun, sekalipun sudah menikah, seorang perempuan tidak terlibat dalam transaksi seperti pengalihan tanah, menerima atau memberi sawah sebagai gadaian, perdagangan ternak, membeli rumah, mempertunangkan anak atau mengawinkan mereka, menangani perselisihan, bertindak sebagai saksi dalam suatu perjanjian, mengambil bagian dalam musyawarah kampong, dsb. Semua itu adalah bidang kegiatan suami. ${ }^{40}$

\section{Dalam Religi}

Setelah terjadi letusan Gunung Toba yang kedua, kepercayaan Mulajadi Nabolon diimbangi dengan kepercayaan parmalim, dan sipelebegu (agama leluhur). Ritual kepercayaan Mulajadi Nabolon dipimpin Eng dan Lang dengan falsafah tuho parngoluan. Ritual kepercayaan parmalim dipimpin oleh seorang raja dengan falsafah suhi ni ampang na opat. Sedangkan kepercayaan sipelebegu, kegiatan ritualnya dipimpin oleh dukun. Mereka tidak memiliki dasar falsafah yang jelas, karena dukun yang menentukan dan mengatur segala sesuatunya. Dengan kebudayaan yang bersifat patrilineal, maka yang berperan dalam kepercayaan-kepercayaan tersebut adalah kaum laki-laki. Perempuan tidak memiliki peran, kecuali berperan sebagai medium (sibaso hasandaran) hadirnya roh-roh dalam kepercayaan sipelebegu. Dalam kehidupannya sehari-hari, para sibaso hasandaran tersebut adalah perempuan yang oleh masyarakat diakui dan dikenal baik sebagai sibaso atau dukun beranak (yang membantu kaum ibu melahirkan). ${ }^{41}$

\section{Simpulan}

Masyarakat Batak Toba adalah masyarakat patrilineal, masyarakat marga, sehingga eksistensi perempuan dalam masyarakat dan adat tergantung pada ayah atau suaminya. Di dalam kehidupan rumah tangga, perempuan merupakan milik suaminya. Perempuan Batak Toba memiliki peran yang domestik, sebagai rekan dalam melaksanakan kegiatan rumah tangga. Jika seorang perempuan menjadi janda karena kematian suaminya, maka kuasa atas isteri berpindah ke keluarga terdekat suami jika

\footnotetext{
${ }^{38}$ Vergouwen. 271

${ }^{39}$ Nalom Siahaan, Adat Dalihan Na Tolu: Prinsip Dan Pelaksanaanya (Jakarta: Grafina, 1982).31

${ }^{40}$ Vergouwen, Masyarakat Dan Hukum Adat Batak Toba, 1988.245

${ }^{41}$ Tobing, Makna Wibawa Jabatan Dalam Gereja Batak.44
} 
tidak ada keturunan laki-laki. Namun, jika seorang isteri memiliki anak laki-laki tertua, tetapi belum dewasa, maka keluarga dapat bertindak atas nama anak laki-laki tersebut. Janda yang menikah lagi, adatnya ditentukan oleh suaminya yang baru. Jika hanya memiliki anak-anak perempuan, maka ia akan bergantung pada kebaikan ahli waris suaminya. Kebergantungan juga terjadi pada janda yang tidak menikah dan tidak mempunyai anak, yaitu kebergantungan pada kerabatnya sendiri. Dengan demikian aktualisasi perempuan dalam adat Batak Toba sangat terbatas.

\section{POLA PELAYANAN TUHAN YESUS BAGI PEREMPUAN KRISTEN DALAM KONTEKS ADAT BATAK TOBA}

Adat adalah bagian dari kebudayaan (menurut $\mathrm{KBBI}$, kebudayaan adalah hasil kegiatan dan penciptaan batin manusia seperti kepercayaan, kesenian, dan adat istiadat) yang diciptakan oleh manusia. Hampir semua hal yang menyangkut tingkah laku manusia ditentukan oleh budaya. Nilai-nilai yang berlaku dalam negara, suku, keluarga, ditentukan oleh budaya. Dengan demikian, sadar atau tidak pola hidup dan cara berpikir seseorang dibentuk oleh adat yang berlaku. Namun bukan berarti bahwa seperangkat adat selamanya mengikat dan tidak bisa diubah. Adat bisa menolong manusia mengembangkan dirinya dengan baik, tetapi juga dapat membuat manusia menyimpang dari tujuan hidupnya, karena adat tidak lepas dari dosa. Tolok ukur baik buruknya adat adalah Firman Allah.

Menurut Y. Tomatala, "Model Transformasi" dalam teologi kontekstualisasi menyatakan, bahwa Allah ada di atas budaya, dan melalui budaya itu pula Allah menggunakan elemen-elemen kebudayaan untuk berinteraksi dengan manusia. Bila seseorang dibaharui Allah, maka inti kebudayaannya juga dibaharui (2 Korintus 5:17). ${ }^{42}$

Yesus datang ke dunia mendobrak budaya patriakhat yang ada. Perhatian Yesus terhadap kaum perempuan telah mengubah budaya dan adat pada masa itu, yang memandang perempuan memiliki status yang lebih rendah dari laki-laki. Pertemuan Yesus dengan perempuan Samaria di dekat sumur merupakan sebuah peristiwa penting, karena Yesus melakukan tindakan yang tidak sesuai dengan adat atau kebiasaan pada masa itu (Yohanes 4:27). Jika adat yang dibuat oleh manusia telah menciptakan kesenjangan sosial, seksual, ekonomi, dsb, maka sebaliknya Yesus telah datang dan mengatasi kesenjangan yang ada.

Dengan demikian dalam melaksanakan pelayanan terhadap kaum perempuan Kristen dalam konteks adat Batak Toba, diperlukan keberanian untuk mengubah paradigma berpikir dan tindakan yang tidak sesuai dengan kebenaran Firman Tuhan.

Seorang perempuan dapat berperan sebagi isteri yang baik apabila hidupnya berpusat pada Allah. Relasi dengan Allah tidak bergantung pada suami. Sebagai perempuan Kristen yang diatur oleh adat, setiap isteri memang harus memiliki sikap menolong, menghormati, dan mengasihi suaminya. Hal tersebut dilakukan karena ketaatannya pada Firman Allah yang menyatakan bahwa isteri adalah penolong bagi suami.

Nilai atau makna seorang perempuan bukan semata-mata didasarkan pada ada atau tidak adanya anak yang dilahirkan, tetapi oleh ketaatan dan kesetiaannya pada Allah. Jika pernikahan tidak dikarunia keturunan, itu tidak berarti bahwa pernikahan itu gagal atau pasangan itu mendapat kutukan dari Tuhan. Anak adalah karunia Tuhan, oleh sebab itu jika Tuhan tidak memberikannya, itu juga dalam rencana Allah yang indah. Jika

\footnotetext{
${ }^{42}$ Tomatala, Teologi Kontekstualisasi: Suatu Pengantar.79
} 
dalam adat, kemandulan isteri bisa menjadi penyebab perceraian, karena dipandang sebagai sesuatu yang merendahkan suami, maka di dalam kebenaran Firman Tuhan, perempuan Kristen yang mandul tidak boleh diperlakukan demikian. Allah membenci perceraian (Mat. 2:14-16; Mark. 10:65-8; 1 Kor. 7:2-4). Karena yang menentukan makna dan martabat kemanusiaannya bukanlah anak yang dilahirkan, tetapi oleh ketaatan dan kesetiaannya pada Allah. Seorang isteri yang tidak melahirkan anak tetap dapat berperan dalam rumah tangga dan masyarakat. la dapat menjadi perempuan yang dikenal saleh oleh masyarakat dengan ketaatan kepada Allah dan dalam ibadah. Kemampuan untuk melahirkan anak-anak tidak mewakili satu-satunya panggilan dalam hidup seorang perempuan

Bagi perempuan yang dikarunia anak, menjadi seorang ibu bukanlah sekedar sebagai kewajiban semata. Perempuan Batak perlu menyadari bahwa itu adalah tugas yang penting dalam kerangka Penciptaan dan pemeliharaan Allah yang baik bagi umat manusia.

Dalam status sebagai janda, seorang perempuan tetap berharga bagi Tuhan dapat menjadi berkat bagi keluarga dan orang lain. Bagi janda-janda yang masih memiliki anakanak yang belum dewasa, mereka bekerja keras untuk memenuhi kebutuhan keluarga, membesarkan dan mendidik anak-anak untuk hidup sesuai dengan kehendak Tuhan. Seorang janda yang taat kepada Tuhan, tidak perlu kuatir ataupun takut akan apa yang akan terjadi, karean Allah akan selalu mendengar seruannya (Kel. 22:23), membelanya dari ketidakadilan (Ulangan 10:18, Mzm. 68:6), menjaga senantiasa, dan Tuhan akan menghakimi orang yang menindasnya (Mal. 3:5).

Bagi perempuan yang tidak menikah, di hadapan Allah mreka tetap memiliki martabat, dan hidup mereka dapat dipakai untuk melayani dan memuliakan Allah, sebagaimana Dorkas (Kisah 9:36-43). Oleh sebab itu, hidup tanpa pernikahan bagi seorang perempuan bukanlah sesuatu yang hina dalam pandangan Allah. Tidak ada ayat dalam Alkitab yang menyatakan bahwa, tujuan akhir Allah bagi seorang perempuan adalah menemukan pasangan dan melahirkan.

Yesus menginginkan saksi di mana-mana. la dapat memakai perempuanperempuan yang saleh untuk menjadi saksi di kehidupan rumah tangga, masyarakat, dan religi. Oleh sebab itu, sekalipun tidak meninggalkan hakikat dan tanggung jawabnya, perempuan Batak Toba harus mendapatkan kesempatan seluas-luasnya untuk berkarya dalam hidup bermasyarakat dan melayani Tuhan. Firman Allah tidak menyatakan bahwa perempuan hanya diciptakan untuk memenuhi fungsinya dalam pernikahan, tetapi Allah ingin perempuan melaksanakan perintah dan memuliakan-Nya. Oleh sebab itu, tidak ada alasan untuk melarang perempuan untuk memiliki jabatan atau pelayanan.

Alkitab menyatakan bahwa Allah mengaruniakan talenta dalam pelayanan, baik hikmat, pengetahuan, iman, penyembuhan, ataupun bernubuat (1 Kor. 12:4-31) kepada masing-masing pribadi, bukan hanya kepada kaum laki-laki atau kaum perempuan saja. Allah tidak memberikan karunia tersebut berdasarkan jenis kelamin. Allah tidak membuat pembatasan dalam pelayanan. Pelayanan dapat dilakukan berdasarkan talenta dan karunia yang diberikan Allah. Dengan demikian, perempuan Batak Toba dapat melayani Tuhan dengan peran yang sesuai dengan talenta atau karunianya masing-masing.

\section{PENUTUP}


Obyek penginjilan adalah manusia, setiap manusia merupakan unsur pokok dalam masyarakat. Maka menginjili orang-orang dalam masyarakat harus memahami situasi masyarakat, dengan demikian baru dapat berhasil baik.

Dalam pelayanannya di bumi, Yesus menghadapi banyak halangan budaya, antara lain adanya diskriminasi gender. Namun Yesus berhasil melakukan pelayanan dalam kondisi masyarakat dan budaya di mana IA berada. Jika budaya memandang perempuan dengan rendah, tetapi Yesus justru menghargai mereka. Yesus menyatakan bahwa kedatangan-Nya ke dunia tidak hanya mengasihi kaum laki-laki, tetapi IA datang untuk semua orang.

Dalam melaksanakan pelayanan terhadap kaum perempuan Kristen dalam konteks adat Batak Toba, diperlukan keberanian untuk mengubah paradigama berpikir dan tindakan yang tidak sesuai dengan kebenaran Firman Tuhan. Penilaian terhadap kaum perempuan dalam masyarakat Batak Toba tentu menyimpang dari hakikat penciptaan, bahwa perempuan diciptakan Allah sederajat dengan laki-laki. Perempuan dan laki-laki mempunyai tugas dan tanggung jawab yang sama untuk menaklukan dan memenuhi bumi. Dengan demikian seluruh potensi yang ada dalam diri perempuan seharusnya dapat diberdayakan untuk memenuhi tugas dan tanggung jawab tersebut. Sekalipun konsep berpikir masyarakat Batak Toba sudah sedemikian melekat dari generasi ke generasi, tetapi bukan berarti bahwa konsep tersebut tidak dapat diperbaiki. Karena itu masyarakat Kristen Batak Toba harus hidup sesuai dengan Firman Tuhan, dan harus tetap menghargai dan melaksanakan adat, jika adat tersebut tidak bertentangan dengan Alkitab dan harus berani merevisi adat yang tidak sesuai dengan Firman Tuhan. Pada bagian lain masyarakat Kristen Batak Toba tidak boleh memandang rendah kaum perempuan, dan harus mengasihi mereka sebagaimana Allah juga menghargai dan mengasihi mereka, dengan memberikan kesempatan kepada kaum perempuan mengaktualisasikan diri dalam masyarakat melalui profesi ataupun pekerjaan yang sesuai dengan kemampuannya masing-masing

\section{Daftar Pustaka}

David J, \& Rommen Edward Hesselgrave. Kontekstualisasi, Makna, Metode, Dan Model. Jakarta: BPK Gunung Mulia, 1996.

Evans, Mary. Women in the Bible. England: Itervarsity Press, 1984.

Geldenhuys, Norval. The Gospel Of Luke. Grand Rapids, Michigan: W.M.B Eerdmans Publising Company, 1979.

Grady, J. Lee. 10 Kebohongan Yang Diberitahukan Gereja Kepada Wanita. Batam: Gospel Press, 2004.

Guthrie, Donald. Teologi Perjanjian Baru I. Jakarta: BPK Gunung Mulia, 1991.

Hutabarat, Rainy. "Perempuan Dalam Budaya Batak: Boru Ni Raja, Inang Soripada Dan

Pembuka Hubungan Baru." 55th ed. Gema Duta Wacana, 1999.

Indonesia, Lembaga Biblika. Injil Lukas. Yogyakarta: Kanisius, 1981.

Jacobs, Cindy. Wanita Pilihan Allah. Yogyakarta: Yayasan Andi, 1999.

Lees, Shirley. The Role Of Women. England: Intervarsity Press, 1984.

Morris, Leon. Teologia Perjanjian Baru. Malang: Gandum Mas, 1996. 
Owens, John Joseph. Analytical Key to the Old Testament Vol I. Grand Rapids, Michigan: Beker Book House, 1994.

Packer, J.L. , Meril C.Tenney, William White., Jr. Ensiklopedi Fakta Alkitab 2. Malang: Gandum Mas, 2001.

Pr. St Darmawijaya. Perempuan Dalam Perjanjian Baru. Yogyakarta: Kanisius, 1991.

Rahmiati. "Veritas" 1, no. April (2000).

Siahaan, Nalom. Adat Dalihan Na Tolu: Prinsip Dan Pelaksanaanya. Jakarta: Grafina, 1982.

Sianipar, S.H.W. Tuho Parngoluan, Ruhut Ni Adat, Poda Ni Uhum, Pangalaho Ni Padan. Medan: Pustaka Gama, 2001.

Stott, Jhon. Isu-Isu Global. Yayasan Bina Kasih/OMF, 1994.

Tobing, A.M Lumban. Makna Wibawa Jabatan Dalam Gereja Batak. Jakarta: BPK Gunung Mulia, 1996.

Tomatala, Y. Teologi Kontekstualisasi: Suatu Pengantar. Malang: Gandum Mas, 2007.

Vergouwen, J.C. Masyarakat Dan Hukum Adat Batak Toba. Jakarta: Pustaka Azet, 1986.

Vergouwen, J.C. Masyarakat Dan Hukum Adat Batak Toba. Jakarta: Pustaka Sinar

Harapan, 1988.

Wongso Peter. Tugas Gereja Dan Misi Masa Kini. Surabaya: Yakin, 1981.

Yewangoe, A.A, Dkk. Kontekstualisai Pemikiran Dogmatika Di Indonesia. Jakarta: BPK Gunung Mulia, 1996. 